\title{
Yeni Anayasadan Yerel Beklentiler: Ăgrı'da Bir Saha Araştırması
}

DOI NO: 10.5578/JSS.6611

\author{
Hasan Güler ${ }^{1}$
}

Coşkun Taştan ${ }^{2}$

\section{Özet}

Türkiye'de özellikle 2011 genel seçimlerinden sonra, yeni anayasa yapılması ile ilgili tartışmalar sürekli olarak gündemde yer tutmaktadır. Halkın bu konudaki beklentileri, ülke çapında yapılan çalışmalarla çeşitli biçimlerde ifade edilmişse de yerel düzeyde konuyla ilgilenen çalışmalar yok denecek kadar azdır. Bu boşluğu nispeten doldurmayı amaçlayan araştırmamız, A ğrı'da yaşayan insanların yeni anayasadan beklentilerini ortaya koymaktadır. Bu beklentiler, bu çalışmada iki ana tema etrafinda ele alınmaktadır. İlkin, yeni anayasanın biçimi ile ilgili beklentiler ortaya konmaktadır. İkinci olarak, içerik ve işlev bakımından yeni anayasadan halkın beklentileri araştırılmaktadır. Araştırma kapsamında, (üyelik esasına göre) toplam 22.401 kişiyi temsil eden sendika, meslek odası ve sivil toplum kuruluşunun yanı sıra, bazı sosyolojik gruplart temsil eden kanaat önderlerinin yer aldiğ cevaplayıcı kitlesiyle 30 "derinlemesine mülâkat" ve 2 "odak grup çalışması" gerçekleştirilmiştir. Araştırma, ülkenin temel sorunlarının yeni bir anayasa ile çözebileceğine dair beklentiler olduğunu ortaya koymaktadır. Bu beklentiye sahip insanlar, bir an önce yeni anayasanın yapılması gerektiğine inanmaktadır. Yeni Anayasa'nın özellikle temel hak ve hürriyetlere öncelik vermesi, diğer konuları kanunlara bırakması gerektiği yönündeki görüş ön plana çıkmaktadır. Yeni anayasanın kısa, net ve anlaşılır olması yönündeki beklentiler de araştırmanın ortaya koyduğu bulgular arasındadır. Konuya hukukî açıdan değil, sosyolojik açıdan yaklaşan çalışmanın bulguları, rapor halinde TBMM Başkanı Cemil Çiçek'e sunulmuştur.

Anahtar Kelimeler: Halkın yeni anayasadan beklentileri, Ăgrı'da saha araştırması, yeni Türk anayasası.

\footnotetext{
${ }^{1}$ Yrd. Doç. Dr., Uşak Üniversitesi, Sosyoloji Bölümü. gulerhas@gmail.com

${ }^{2}$ Yrd. Doç. Dr., Ağrı İbrahim Çeçen Üniversitesi, Sosyoloji Bölümü. ctastan@gmail.com
} 


\title{
Local Expectations from the New Turkish Constitution: A Survey in A $\breve{g} r \mathbf{r}$
}

\begin{abstract}
Since the 2011 general elections in Turkey, debates over a new constitution have remained hot in public agenda. This has kept alive people's interest in the new constitution. People's expectations have been expressed in different ways through country-wide studies. However, studies dealing with people's expectations on local levels are less than few in numbers. To fill this gap to a certain extent, this study aims at finding out the expectations of people of an eastern province in Turkey, Ağrl, from the new Turkish constitution. For this purpose, 30 in-depth interviews and 2 focus group interviews have been conducted. A group of people who can be defined as "leaders of public opinion" were chosen as the sample of the study. These people consisted in the leaders of main local NGO's and professional chambers, who literally represent some 22.401 people (based on the membership criteria). Beside, the representatives of some sociological groups like "tribes" ("aşirets") and religious communities (jama'ats) were included in the interviews. The study shows that there is an expectation among the people that a new constitution will potentially solve the basic problems in the country. Because of this expectation, people believe that the new constitution should be made and brought into force as soon as possible. The study also shows that there are expectations about the forms and the contents of the new constitution: It should be brief, clear and understandable. Also, the respondents believe that it should focus on fundamental rights and freedoms, leaving other issues to the laws. The research, the final report of which has been submitted to the president of TBMM, Cemil Çiçek, takes a sociological point of view rather than a judicial approach.
\end{abstract}

Keywords: People's expectations from the new constitution, field research in A $\breve{g r l}$, new Turkish constitution.

\section{Giriş}

Farklı akademik disiplinler tarafından farklı biçimlerde tarif edilebilecek olan Anayasayı, sosyolojik bakış açısıyla şöyle tanımlayabiliriz: Farklılıkların bir arada nasıl yaşayacağını gösteren, azami bir toplumsal uzlaşıya dayanan toplumsal sözleșme metni. Anayasaların bir toplumsal sözleşme metni olarak algılanmasının tarihi çok uzundur. Batı düşüncesinde toplumsal sözleşme teorisi, devlete neden ihtiyaç duyulduğunu anlatan ve meşruiyetinin kaynağını gösteren temel teorilerden biridir (Akdemir ve Hepaksaz, 2010: 121). Bu teoriye göre toplumsal kaostan kurtulmanın yolu, toplumu oluşturan üyelerin kendi rızaları ile haklarının bir kısmını devlete terk etmelerinden geçer. $\mathrm{Bu}$ sayede bir toplumsal sözleşme ile anarşi ortamından düzene geçileceği var sayılır. Batı toplumlarında Magna Carta ile başlayan hukuk devleti fikrini (İlal, 1968: 211) toplumsal sözleșme düşüncesinin ilk kaynaklarından sayabiliriz. Toplumsal sözleşme teorisi bir 
dizi ön kabulü içinde taşımaktadır. Bu kabullerden en önemlisi Hobbes’un fikirlerine dayanır. Hobbes'un düşüncelerine göre, insanlar özünde bencildir ve kuralsızlıktan kurtulmak için bir sözleşme ile doğal haklarının bir kısmını sözleşme ile egemene teslim ederler. Doğal hukuk öğretisinin geçmişi antik Yunan'a kadar uzanmaktadır. Bu öğreti, esas olarak, doğuştan kazanılan haklar varsayımına dayanmış ve bu haklara adalet kavramı içinde yer vererek, onları eşitlik, özgürlük ve kardeşlik ilkeleri üzerine temellendirmiştir. Antik çağda özellikle Stoa Okulu tarafından sistematize edilen doğal hukuk anlayışı ortaçağ boyunca, Hıristiyanlığın ilkeleri çerçevesinde kavranmış ve daha önemlisi kilisenin baskısı altında kalmıştır (Bulut, 2009). Doğal hukuka bağlı haklar ile liberal düşünce akımının öngördüğü özgürlükler arasındaki bağlantı, Ortaçağı takiben Rönesans'la, aydınlanma döneminin düşünürleri tarafından kurulmuştur. Grotius ve Pufendorf ilahi adalet öğretisine karşı çıkarak sivil iktidarın insani bir kurum olduğunu öne sürerek bu öğretinin karşısında yer alırlar. Onlar göre, "siyasal toplum ya da sivil devlet, insanların özgürlüklerinin bir kısmını bir üçüncü şahsa devretmek suretiyle, gönüllü olarak birleşmelerini sağlayan bir ön antlaşmayı varsaymaktadır" (Abeles, 1995: 19) toplumsal sözleşme fikri daha sonra Hobbes, Locke ve Rousseau tarafindan geliștirilmiștir. Günümüz ulus-devletlerinin, Durkheim'ci terminolojiden hareket edersek "anomi"den ç1kış1, düşünsel alt yapısını toplumsal sözleşme fikrinde bulabileceğimiz anayasalardan geçeceğini söylemenin yanlış olmayacağı kanaatindeyiz.

Batı düşünce geleneği içinde oluşan yukarıda bahsettiğimiz fikirler zamanla dünyanın geri kalanına yayılmıștır. 19. Yüzyılda "Sened-i İttifak" ile başlayan padişahın yetkilerini sınırlamaya yönelik girişimler Osmanlı İmparatorluğu'nun da bu süreçten uzak kalamayacağının kanıtı olmaktadır. Türkiye'nin Anayasa tarihine baktığımızda "Sened-i İtttifak" ile başlayan süreç, modern amme hukuku müesseselerinin ortaya çıkışını sağlayan "Tanzimat Fermanı", "Birinci Meşrutiyet" ve "İkinci Meşrutiyet" ile devam etmiştir (Okandan, 1949: 14). Birinci meşrutiyet döneminde kaleme alınan Kanun-i Esasi, Türk toplumunun anayasa ile ilk tanışmasıdır (Akgün, 2010:148). Bu ilk tanışmadan sonra sırasılyla 1921, 1924, 1961 ve 1982 anayasaları yapılmıştır (Aldıkaçtı, 1973; Özbudun, 2000; Akgül, 2010; Yazıc1 ve Yazıc1, 2011; Yüzbaşığlu: 2013; Gözler, 2013). Anayasalar yazılı metinlerdir ve oluşturuldukları zamanın ruhunu yansıtırlar. Salt metinsel olarak demokrasi ve özgürlük getirdiklerini söylemek güçtür. Çünkü nasıl bir ortam içinde yapıldıklarına ve uygulamalarına da bakılması gerekmektedir. Bu noktada Bülent Tanör Türkiye'de yürürlüğe giren anayasalar ile ilgili şu yorumlarda bulunmuştur:

1921 Anayasası, hazırlanış ve kabul özellikleri bakımından Osmanl1Türk anayasacılığının en demokratik, belki de tek demokratik örneğidir. 1876 Anayasası padişahın atadığı bir komisyonca hazırlanmış ve padişahın 
tek yanlı iradesiyle ortaya çıkmış bir Ferman-Anayasa'ydı... 1924 Anayasası, bağımsız davranmayı başarmış olsalar da, adaylıklarını ve milletvekillikleri Mustafa Kemal'e borçlu kişilerden oluşan bir meclis tarafından yapılmış olacaktır. 19611982 Anayasaları ise askeri darbeler ve resimlerin ürünüdürler (Tanör, 1995: 207).

Anayasa ile ilgili olarak tarihimize baktığımız zaman yapılan anayasaların ya olağanüstü şartların bir sonucu olarak ya da askeri darbeler sonrası kaleme alındığını görüyoruz. Bundan dolayı bu anayasaların, toplumun yapısını önemseyen ve evrensel hukuk normlarını merkeze alan bir anlayışla kaleme alındıklarını söylemek oldukça güçtür. Özellikle yürürlükte olan mevcut 1982 anayasası devleti merkeze alan yap1s1 ile toplumun ihtiyaçlarını karşılama noktasında yetersiz kalmakla eleştirilmektedir. Birçok maddesinin değiştirilmiş olması toplumun gerisinde kaldığının açık delili olarak karşımızda durmaktadır. Yeni yüzyılda olağan şartlar altında ortaya çıkmış ve toplumun tüm kesimlerinin görüşlerini önemseyen sivil bir anayasanın yapılması elzem olmuştur. Zamanın ruhu anayasa yapım sürecinde yeni bir paradigmaya işaret etmektedir. Bu paradigma değişikliği, daha önceki kurucu meclis sistemi içinde görece kapalı bir yapıdan, toplumun tüm kesimlerinin sürece dahil edildiği ve bu sürecin sonunda ortaya çıkan anayasa metni üzerinde uzlaşıldığ 1 demokratik bir anayasa yapım ve kabul surecini geçildiğini göstermektedir (Gülener, 2011). Bundan dolayı Türkiye'nin yeni anayasa yapım süreci, en az içeriği kadar demokratik teamüllerin gelișmişliğinin bir göstergesi olma baskısı ile karş1 karşıya olduğunu söyleyebiliriz. Her ne kadar kimi siyasetçiler ve hukukçular yeni anayasanın Türkiye'nin tüm sorunlarını çözmek gibi bir işlevinin olamayacağını sıklıkla dile getiriyor olsalar da, yeni anayasanın Türkiye' deki etnik, dinsel ve kültürel sorunları kökten çözmesi gerektiğine dair bir beklenti halk arasında giderek büyümektedir. Kürt sorunu; başörtüsü sorunu; imam-hatip lisesi mezunlarının üniversiteye girişi gibi kemikleşmiş sorunların yanı sıra Alevîlerin kamusal alana dair talepleri; azınlıkların dini okulları ve mülkiyetleri gibi giderek önem kazanan sorunların da yeni anayasa tarafından çözülmesi yönündeki beklentiler (gerçekçi olup olmadıkları bir yana) açık ve net biçimde önümüzde durmaktadır.

Yeni anayasa hazırlıkları içerisinde olan hükümetin bu konudaki çalışmaları, ülke içerisindeki aktörler ve halk tarafından olduğu kadar Avrupa Birliği tarafından da yakından izlenmektedir. Bu nedenle uzlaşmacı bir tutumla ve ülke içerisindeki görüşleri olduğu kadar evrensel ölçüleri de gözeten bir anlayışla yeni anayasanın inşa edilmesi amaçlanmaktadır. Avrupa Birliği'ne üye olma yolundaki Türkiye'nin, yeni anayasasını hazırlarken dikkate alması gereken (Avrupa İnsan Hakları Sözleşmesi (European Convention on Human Rights); demokrasi, hukukun üstünlüğü gibi ilkeler ve Avrupa Konseyi üyesi ülkelerin ortak değerleri gibi) uluslar 
arası normların yanı sıra, ülke içerisinde ortaya çıkan ve her geçen gün büyüyen iç dinamikler söz konusudur. Ülkemizin iç dinamiklerine dayanan beklentilerin ayrıntılı olarak ve dikkatle analiz edilmesi, bu nedenle çok önemlidir.

12 Haziran 2011 genel seçimlerinden sonra kurulan Adalet ve Kalkınma Partisi hükümeti, mevcut anayasanın değiştirilmesinin gerekli olduğu fikrinden hareketle, toplumun farklı kesimlerinin bu konudaki beklentilerini de gözeterek, yeni bir anayasa hazırlamayı öncelikli icraatlarından biri olarak ilân etti. Geçen zaman içerisinde bu politik irade ile bu konudaki toplumsal beklentiler birleşti ve neticede güçlü bir politik talebe dönüştü. Farklı toplumsal kesimler tarafından farklı biçimlerde ifade edilen bu talep, söz konusu toplumsal kesimlerin siyasal temsilcileri tarafindan da dillendirilerek sürekli canlı tutulmaktadır. Bu taleplerin geldiği noktaya baktığımızda açıkça görülen şey şudur: Toplumun hemen her kesimi ülkemizin yeni bir anayasaya ihtiyaç duyduğu konusunda hemfikirdir. Ancak bu köklü değișimin hangi noktalarda ve nasıl yapılması gerektiği konusunda toplumsal taleplerin birbirinden farklılık arz ettiğini gözlemliyoruz.

\section{Araştırmanın Amacı ve Kapsamı}

Elinizdeki çalışma, yeni anayasamızın biçim ve içerik bakımından nasıl olması gerektiğine dair Ağrı ili sivil toplum liderleri ve kanaat önderlerinin beklentilerini ortaya koymayı hedeflemektedir. Ağrı ili, 12 Eylül 2010 tarihinde mevcut anayasada değişiklikler öngören kanun ile ilgili halkoylamasında \%95.8 oranında "evet" oyu kullanmıştır. Bu oran, iller bazında Türkiye'deki en yüksek "evet” oranıdır. Siyasal konjonktürdeki ikincil anlamlarından ${ }^{1}$ bir an için soyutlayarak bu oranı düz bir okuma ile yorumlarsak, Ağrı'nın 1982 Anayasası'nın değiștirilmesi yönündeki taleplerin en yoğun biçimde ifade edildiği bir şehir olduğu sonucuna varırız. $\mathrm{Bu}$ talebin farklı toplumsal gruplar tarafindan farklı biçimlerde dillendirildiğine son yıllarda hemen her gün tanık olmaktayız.

Yeni anayasadan beklentileri anlamaya yönelik ulusal düzeyde çalışmalar yapılmış ve sonuçlar raporlanarak yayınlanmıştır. Ancak konuyu iller bazında ele alan çalışmaların sayısı yok denecek kadar azdır. Bu çalışmamız, Ağrı ili sivil toplum liderleri ve kanaat önderlerinde ifade bulan beklentiler üzerine odaklanarak bu açığı belirli ölçüde kapatmaktadır.

1 Siyasal konjonktürü hesaba katarak baktığımızda ise bu oranın Adalet ve Kalkınma Partisi ile muhalefet partileri arasındaki çekişmede bir taraf tutma eğilimini yansıttığı da âşikârdır. 


\section{Araştırmanın Yöntemi}

Çalışmamızda niteliksel araştırma yöntemlerinden "yüz yüze derinlemesine mülâkat" ${ }^{2}$ ve "odak grup görüşmesi" ${ }^{3}$ kullanılmıştır. Bu veri toplama yöntemleri, istatistiksel temsil veyahut parametrik tasvir kaygıs1 güdülmeksizin seçilen deneklerin belirli konulardaki fikir, alg1 ve tutumlarının sözel yollarla ifade edilmesine dayanır. Başka bir deyişle bu veri toplama yöntemleri fikir ve kanaatlerin sayısal olarak ve yüzdelik oranlarla gruplandırılmasına dayanmaz. Bunun yerine, belirli konulardaki fikir, kanaat ve tutumların sözel yollarla ifade edilmesi sonucunda ortaya çıkan genel görünüm niteliksel olarak rapor edilir. Belirli dezavantajları da olmakla birlikte bu yöntemler, toplumsal olguların beșerî karakterlerini anlamak, ifade etmek ve tasvir etmek için daha elverişlidir. Niteliksel araştırma yöntemlerinden yararlanmanın getirdiği en önemli avantaj, sayısal araçlarla ifade edilmesi güç (veya kimi zaman imkânsı) olan toplumsal gerçekliklerin yerli yerinde anlaşılabilmesine ve bu gerçekliklerin ifade edilebilmesini kolaylaştırmasıdır. $\mathrm{Bu}$ nedenle bu yöntemler, geçtiğimiz yüzyılın ikinci yarısından itibaren dünya sathında giderek artan bir akademik ilgiye mazhar olmuştur.

Bilimsel araştırma yöntemlerinde iki ayrı yol olarak görülen niteliksel ve niceliksel yöntemler arasındaki farkları ve bu iki yöntemin avantajlarının ve dezavantajlarının neler olduğunu burada ana hatlarıyla ortaya koymamız yararlı olacaktır. Bu iki yöntemin tanımını ve birbirine karşı üstünlüklerini belirleyen şey bilimsel araştırmaya konu olan nesnenin doğası ile yakından ilgilidir.

Niteliksel ve niceliksel yöntem arasında bir seçim yapmak bazen araştırma önceliklerine göre yapılan bir tercihle, bazen de araştırma nesnesinin doğasının getirdiği kısıtlamalar tarafından belirlenir. Araştırma nesnesinin nitelikleri ile ilgileniyorsak, bu nitelikleri ifade eden yöntemlere ihtiyaç duyarız. Araştırma nesnesinin nicelikleri ile ilgileniyorsak, nesneyi sayılar kullanarak tarif etmemizi sağlayan araçlara başvururuz. Örneğin bir ağacın dalında kaç elma olduğu ile ilgileniyorsak, kaçınılmaz olarak niceliksel yönteme başvurmamız gerekir. Aynı elmaların ekşi mi yoksa tatlı

2 Derinlemesine mülâkat: Belirli bir konuda cevaplayıcıların görüşlerini etraflıca irdeleyerek araştırma sorularına cevap bulmaya yarayan araştırma yöntemidir. Bu yöntemde esas olan rakamlar, yüzdelikler ve istatistikler (nicelik) değil, cevaplayıcıların odaklandığı görüşler ve ön plana çıkardıkları fikirlerdir. Bu nedenle bu yöntem "niteliksel araştırma yöntemi" olarak tanımlanır.

3 Odak grup: Yaş, cinsiyet, ekonomik durum, ideolojik tutum vb. değişkenler bakımından heterojen olan gruplar oluşturmaya dayanan niteliksel sosyolojik araştırma yöntemidir. Belirli bir konuda fikirlerini ifade etmeleri için bir araya getirilen cevaplayıcıları izleyen araştırmac1, katılımcıların belirli konulardaki düşüncelerini ifade eden cümlelere odaklanarak araştırma sorularına yanıt arar. 
mı olduğu ile ilgileniyorsak, niteliksel yöntemden başka çaremiz yoktur. Elmaların ne kadarının tatlı ne kadarının ekşi olduğu ile ilgileniyorsak, niteliksel ve niceliksel yöntemi birlikte kullanırız.

Niteliksel yöntem ile niceliksel yöntemin birbirinden ne kadar farklı ya da birbirine ne ölçüde yakın iki yöntem olduğu konusu, eşyanın niteliği ile niceliği arasında kesin bir ayrım olup olmadığ 1 ile ilgilidir. Nitelik ile nicelik arasında her zaman bir ilişki olduğunu, buna bağlı olarak da niteliklerin niceliklere, niceliklerin de niteliklere dönüşebileceğini iddia edebiliriz. Örneğin bir melodinin güzel, hoș, acıklı, neșeli gibi sıfatlarla tarif edilmesi mümkün olduğu gibi, bu melodinin ses frekansları bakımından incelenerek rakamlarla ifade edilmesi de mümkündür.

$\mathrm{Bu}$ iki yöntem bazen birbirini dışlayan karşıt iki yöntem gibi görülse bile onları birbirini tamamlayan iki farklı yöntem olarak görmek en doğrusudur (Newman ve Benz, 1998: 1). Birlikte kullanıldıklarında araştırma nesnesini daha fazla tanıma ve tanımlama imkânı doğar (Newman ve Benz, 1998:110).

Niteliksel araştırma yöntemi, farklı araçlarla ve farklı biçimlerde gerçekleştirilebilir: Odak grup görüşmesi; döküman toplama; doğal gözlem; görsel ve işitsel materyal derleme ve mülâkat gibi. Bunlar arasında sosyal bilimlerin en fazla başvurduğu biçim mülâkattır (Perakyla, 2005: 869). Çünkü mülâkat, “...araştırmacının başka türlü ulaşamayacağı gerçeklik alanlarını (meselâ insanların öznel deneyimlerini ve tutumlarını) erişime açar" (Perakyla, a.g.e.). Fen bilimlerinden farklı olarak sosyal bilimlerin çalışma nesnesi (yani insan) düşünme ve konuşma yeteneğine sahiptir (Seidman, 2006:10). Bu nedenle insanların davranışlarını ve eylemlerini belirli sosyal-kültürel bağlama oturtabilmek için doğrudan kişinin kendi düşüncelerine başvurma imkânı vardır.

Araştırmamız kapsamında niteliksel veri toplama yöntemi yardımıyla veri toplamak için, belirli sorular ve odak temaları hazırland. Hem derinlemesine mülâkatlarda hem de odak grup görüşmelerinde geçerli olmak üzere, toplanması hedeflenen verileri kuşatan iki çatı belirlendi: Birincisi, yeni anayasanın biçimsel özellikleri. İkincisi ise, yeni anayasanın içerik bakımından özellikleri.

Cevaplayıcıların yeni anayasadan biçim bakımından beklentilerini anlamak için şu noktalar ön plana çıkarıldı: "Değiștirilemez madde" kavramı hakkındaki fikir ve kanaatler; anayasanın kısa ve öz mü yoksa uzun ve ayrıntılı mı olması gerektiğine dair fikir ve kanaatler; anayasa yapma yetkisi ile ilgili fikir ve kanaatler ve yeni anayasaya ihtiyaç olup olmadığına dair fikir ve kanaatler.

Cevaplayıcının yeni anayasadan biçimsel beklentilerini anlamak için, bu odak temaların her birini ayrı ayrı sondajlayan sorular hazırland1. 
Cevaplayıcıların yeni anayasadan içerik bakımından neler beklediğini anlamak için ise şu odak temaları ön plana çıkarıldı: 1. Temel haklar, özgürlükler ve ödevler. 2. Siyasal sistem. 3. Siyasal temsil. 4.Toplumsal yap1.

“Temel haklar, özgürlükler ve ödevler” odak teması, anayasanın önemli politik işlevlerinden birini ifade eder. $\mathrm{Bu}$ odak tema hakkındaki fikir ve tutumları ortaya çıkarmak için cevaplayıcının idam cezası, tutukluluk ve yargı süreleri ile ilgili olarak yeni anayasadan ne gibi beklentiler içerisinde olduğuna yönelik sorular yöneltildi. "Siyasal sistem" odak temas1, cevaplayıcının yeni anayasa ile birlikte nasıl bir hükümet modeli beklediğini anlamayı hedeflemektedir. Bu odak noktası etrafinda sorulan sorulara verdikleri yanıtlarla cevaplayıcıların yeni anayasanın başkanlık sistemi mi, parlamenter sistem mi yoksa başka herhangi bir model mi tesis etmesi gerektiği ile ilgili fikirleri açığa çıkarıldı. "Siyasal temsil" odak teması, seçim barajları hakkında cevaplayıcının beklentilerini anlamayı hedeflemektedir. "Toplumsal yap1" odak teması ise, anayasanın sosyolojik işlevlerini ifade eder: Hâl-i hazırda çok hararetli politik çekişmelere de konu olan "ana dilde eğitim" konusu kadar etnik, dinsel ve kültürel uzlaşmazlıklarla baş edilmesi meselesi de bu odak tema altında hazırlanan sorularla araştırıldı.

\subsection{Cevaplayıcı Profili}

İstatistiksel temsilden farklı olan ve "sosyolojik temsil" adını verebileceğimiz bir temsiliyet biçimini esas aldığımızda, araştırmamızda cevaplayıcı olarak yer alan sivil toplum örgütleri, meslek odaları ve sendikaların, 22.401 kişiyi temsil ettiğini söyleyebiliriz. Yukarıda ifade ettiğimiz gibi araştırmamız istatistiksel veriler toplama ve toplumsal gerçeklikleri sayısal verilerle ifade etme yöntemine dayanmadığı için, örneklem belirleme aşamasında "sayısal temsil" kaygısından bağımsız hareket edildi. Bu doğrultuda, 30 derinlemesine mülâkat ve 2 odak grup görüşmesi gerçekleștirildi. Sivil toplum örgütleri ve meslek odalarının yanı sıra, her ne kadar modernleşme sürecinde gözle görülür çözülmeler içerisinde olsa da Ağrı ili ve civarında bugün hâlâ önemli bir sosyolojik yapı olarak varlığını sürdüren "aşiretlerin" önemli üyeleri ve bazı cemaatlerin liderleri ile de derinlemesine mülakatlar yapılarak bulguların temsil gücü artırıld1. Bu özelliklere sahip bir örneklem, Ağrı ilinin yeni anayasadan biçim ve içerik bakımından neler beklediğini niteliksel bakımdan ortaya koymaya elverişlidir.

Derinlemesine mülâkatların kimlerle gerçekleştirileceği konusunda karar alınırken şu ilkeler gözetildi: Her şeyden önce cevaplayıcının, belirli bir politik kesimi ve toplumsal tabanı temsil ediyor olmasina dikkat edildi. Başka bir deyişle cevaplayıcılar, toplumsal bakımdan izole edilmiş ve 
yalnızlık içerisinde olmayan uygun kişiler arasından seçildi. Kanaatlerinin toplumsal izdüşümünün geniş olması için cevaplayıcının sosyal bağlarının güçlü olması gerekir. İkinci olarak cevaplayıcının, fikir alış verişi bakımından etkin olup olmadığına dikkat edildi. Diğer bir deyişle cevaplayııı seçimi yapılırken cevaplayıcının başka insanların fikirlerinden etkilenmeye açık bir toplumsal pozisyonda olup olmadığına bakıldı. Aynı şekilde cevaplayıcının, taşıdığı fikirleri başka insanlara aktarabilecek sosyal konumda olup olmadığ 1 tartışıldı. Bunlarla birlikte cevaplayıcının yeni fikirler üretme kapasitesine sahip olması ölçütü kullanıldı. Bu nitelikleri taşıyan bireyler, araştırmamız kapsamında "kanaat önderi" olarak tanımlanmıştır.

$\mathrm{Bu}$ ilkeler doğrultusunda ilk akla gelen cevaplayıcı profilleri Ağrı ilindeki sivil toplum kuruluşlarının liderleri ve oda niteliğindeki yapılanmaların yöneticileridir. Bunlardan başka, büyük esnaf ve ticaret insanları arasından da seçimler yapıldı. Ayrıca bölgemizin sosyal yapısı gereği belirli nüfus kütleleri üzerinde ideolojik ve kültürel bakımdan etki sahibi olan "önemli bireyler" (cemaat ve aşiret liderleri) de cevaplayıcı profiline dâhil edildi. Tüm bunlar arasından yapılan seçimler sonucunda ortaya çıkan 30 kişi ile derinlemesine mülâkatlar yapıldı ve buna ek olarak 2 odak grup görüşmesi gerçekleştirildi.

Araştırmanın uygulama aşamasında ilk adım olarak, yukarıda sıraladığımız ilkeler çerçevesinde belirlenen 30 kişinin adres ve telefon bilgilerine çeşitli kaynaklar vasıtasıyla (örneğin sivil toplum örgütlerinin liderlerine, Valilik tarafından ilân edilen protokol listesi kullanılarak) ulaşıldı. Randevu usulü ile belirlenen günlerde ve mekânlarda görüşmeler gerçekleştirildi. Derinlemesine mülâkat görüşmeleri iki görüşmecinin işbirliği ile gerçekleştirildi. Görüşmecilerden biri soruları sorup konuşmayı yönlendirirken diğer görüşmeci notlar alarak veri topladı. Odak grup çalışmaları da yine aynı görüşmeciler tarafından organize edilerek izlendi. $\mathrm{Bu}$ şekilde derlenen veriler analiz edilerek rapora dönüştürüldü.

\section{Bulgular}

\subsection{Biçim Bakımından Beklentiler}

\subsubsection{Yeni bir anayasa; hemen şimdi}

Katılımc1lar, her şeyden önce yeni bir anayasaya ihtiyaç olduğu görüşünü net bir dille ifade etmektedirler. $\mathrm{Bu}$ veri, yeni anayasanın meşruiyeti hakkında hukukçular tarafından yapılan tartışmalara önemli bir katkı niteliği taşımaktadır. Değişen ülke ve dünya koşullarının mevcut anayasayı değiştirmeyi bir zorunluluk olarak önümüze getirdiği, mevcut anayasanın (1982 Anayasası) hiçbir zaman ülke şartlarını tam anlamıyla kavramadığı ve Türkiye insanlarının daha iyi bir anayasaya layık olduğu 
görüşü ağırlıklı olarak ifade edildi. Kürt sorunu özelinde yaşanan etnik toplumsal sorunların çözümü ve dinsel aidiyetlerin daha rahat ifade edilebilmesi noktasında yeni anayasa bir çözüm aracı olarak görülmektedir. $\mathrm{Bu}$ nedenle yeni anayasanın bir an önce hazırlanarak yürürlüğe girmesi yönünde açık bir beklenti olduğunu rahatlıkla söyleyebiliriz.

\subsubsection{Kısa; öz; sade ve anlaşıllı bir anayasa}

Cevaplayıcıların yeni anayasanın biçimsel bakımdan nasıl olması gerektiğine dair görüşleri bir kaç noktada yoğunlaşmaktadır. Her şeyden önce anayasanın kısa ve öz olması, dilinin sade olması ve her konu ile ilgili hükümler içermekten uzak olması gerektiğine dair görüş ön plana çıkmaktadır. Köylü ya da kentli, okumuş ya da okumamış her kesimden insanın rahatlıkla anlayabileceği bir dilde yazılması gerektiği ve böyle olursa herkesin anayasayı daha çok sahipleneceği görüşü hâkimdir. Anayasayı az sayıdaki okumuşların (elitlerin) hazırlayarak tüm topluma dayattığ 1 bir metin olarak değil, her kesin ve her kesimin katılımıyla ortaya çıkan; mümkün olduğunca uzlaşma ile oluşturulmuş ortak bir metin olarak görebilmek için sade ve anlaşılabilir olması gerektiği yönündeki görüşler ön plana çıkmaktadır.

\subsubsection{Her maddesi her an değişime açık ama sık sık değişim gerektirmeyen bir} anayasa

Yeni anayasanın istisnasız tüm maddelerinin değiştirilebilir esneklikte olması gerektiği kanaati belirgin biçimde ön plana çıkmaktadır. Öte yandan bu esneklik talebini, anayasayı sık sık değiștirilen ve kısa zamanda "yamalı bohça" haline gelen bir metin olmaktan da korumak gerektiği görüşü ile birlikte düşünmek gerek. Cevaplayıcıların ortak kanaati olarak görebileceğimiz bu fikri şöyle ifade edebiliriz: Prensip olarak anayasanın her maddesinin değişime açık olması gerek ama ortaya çıkan metnin sık sık değişimlere ihtiyaç duymayan gerçekçi bir niteliğe sahip olması da önemlidir. Anayasa, çok uzun vadeli bir metin olarak kaleme alınmalıdır ancak geçici kaygılarla gelecek nesillerin iradesine de ipotek konmamalıdır. Gelecek nesiller anayasa metnindeki herhangi bir maddeyi istedikleri gibi değiştirme özgürlüğüne sahip olmalıdır. Önemli olan, gelecek nesillerin de değiştirme özgürlüğüne sahip oldukları halde değiştirme gereği duymadıkları bir anayasa metni hazırlamaktır.

\subsubsection{Halkın anayasası halk tarafindan onaylanmalı}

Yeni anayasanın en önemli görülen özelliklerinden biri, ülkemizde ilk defa olağan toplumsal şartlar altında, toplumun her kesiminin katkılarına açık bir süreçle birlikte ortaya çıkacak bir anayasa olmasıdır. Bu durum, yeni 
anayasanın meşruiyet kaynağı ile ilgili düşüncelerin de gelişmesine vesile olmaktadır. Yeni anayasa yapma yetkisi kimde olmalıdır? Ağrı ili sivil toplum liderleri ve kanaat önderleriyle yaptığımız görüşmede bu soruya verilen yanıtlarda ön plana çıkan görüş şudur: Yeni anayasanın meşruiyeti, halkın kanaati ile sağlanmalıdır. Başka bir deyişle, anayasa metninin nihai anlamda geçerli sayılabilmesi, yürürlüğe girmesi ve kamu vicdanında meşruiyet bulması için mutlaka halkın onayından geçmesi gerek. Halk kendilerini bir arada tutacak olan metnin meşru sayılması için kendi onayından geçmesini beklemektedir. Cevaplayıcılar arasında bunun aksini savunanlar da vardır. Kimi cevaplayıcılar TBMM'nin bu konudaki en yetkili kurum olduğunu; orada karar alan insanların zaten halk adına iş yaptıklarını ve bu nedenle yeni anayasanın halkoylaması olmasa da meşru olacağını savunmaktadır. Ancak bu görüş, yeni anayasanın meşruiyeti için halkoylamasını şart koşan görüşün yanında oldukça zayıf kalmaktadır.

\section{2.İçerik Bakımından Beklentiler}

\subsection{1. "Cumhur, kendi başkanını seçmeli"}

Yeni anayasanın içeriği ile ilgili olarak Ağrı ili sivil toplum liderleri ve kanaat önderleri tarafından dile getirilen önemli konulardan biri, cumhurbaşkanının seçimi ile ilgilidir. Araştırmamız kapsamında yaptı̆̆ımız görüssmeler neticesinde anayasanın hem toplumsal düzeni hem de siyasal mekanizmayı düzenlemesi gerektiğine dair kanaat oldukça net bir biçimde ortaya çıkmaktadır. Siyasal mekanizmayı olduğu kadar sosyal düzeni de yakından ilgilendiren "cumhurbaşkanının seçilmesi" konusunda ortaya çıkan görüş şudur: Cumhurbaşkanını seçecek olan merci halktır. Bir cevaplayıcının sözleriyle ifade edecek olursak: "Cumhur, kendi başkanını seçmelidir". Genel kanaat cumhurbaşkanının meşru olduğu kadar güçlü de olması için onu halkın onayından da geçirmek gerektiği yönündedir.

\subsection{2. İdamsiz Anayasa}

Temel hak ve hürriyetleri tanımlamak, anayasaların önemli görevlerinden biridir. $\mathrm{Bu}$ nedenle mülâkatlarımızda, temel hak ve hürriyetlerin en önemlisi olan yaşam hakkı ile ilgili olarak yeni anayasadan bir beklenti olup olmadığını ortaya çıkarmaya çalıștık. Bu noktada cevaplayıcıların net biçimde vurguladıkları görüş, insanların doğuştan elde ettikleri yaşam hakkının, hangi nedenle olursa olsun insanlar tarafından ihlâl edilmemesi gerektiği yönündedir. $\mathrm{Bu}$ nedenle idam cezasının da yasaklanması gerektiği ve bu yasağın anayasa tarafindan açıkça telaffuz edilmesi gerektiği yönünde görüş ortaya çıkmaktadır. Bu görüş şöyle özetlenebilir: Şu anki anayasa metninde zaten idam cezası mevcut değil ama yeni anayasada da bu açık bir dille ifade edilmelidir. İdam cezası hakkında sessiz kalan bir anayasadansa onu açıkça yasaklayan bir anayasa, gelecek 
nesiller arasında da yaşam hakkının devlet eliyle bile olsa sona erdirilmesinin temel haklara aykırı olduğu normunun yerleşmesine yardımcı olacaktır.

\subsubsection{Anadilleri önemseyen bir anayasa}

Cevaplayıcıların vurguladığı noktalardan biri de anadil meselesidir. Mülâkat yapılan sivil toplum liderleri ve kanaat önderlerinin tamamı anadillerin anayasa tarafından meşru görülmesi gerektiğini ve bu dillerin koruma altına alınması gerektiğini ifade etmektedirler. Dillerin anayasa tarafından nasıl koruma altına alınabileceği meselesine gelince şöyle bir fikir ön plana çıkmaktadır: Türkçe resmi dil olarak tanımlanmalı ve Türkçe dışındaki diller de eğitim dili olarak kullanılabilmelidir. Anadillerin anayasa tarafından korunması gerektiği konusundaki konsensüse karşın anadilde eğitim konusunda cevaplayıcıların tamamının aynı görüşte olduğunu söyleyemeyiz. Bazı cevaplayıcılar anadilde eğitimin tamamen serbest olması gerektiğini söylerken bazıları belirli şartlar altında anadilde eğitim yapmanın önünü açmak gerektiğini dile getirmektedirler. Cevaplayıcıların öne sürdükleri şartlar arasında ön plana çıkanlar şunlardır: Türkçe'nin resmi dil statüsünün korunması ve her bireyin Türkçe öğrenmesinin sağlanması. Cevaplayıcılar bu şartların sağlanması halinde herkesin kendi anadilinde eğitim alabilmesinin sağlanması gerektiğini ifade etmektedirler.

\subsection{4. "Başkanlık değil parlamenter sistem"}

Cevaplayıcıların siyasal sistemin yapısı ile ilgili anayasal düzenlemeler hakkında önemsedikleri konulardan biri de başkanlık sistemidir. Medyada bu konunun devamlı olarak gündemde tutulması, kamuoyunda başkanlık sistemi hakkında (lehte veya aleyhte) bir duyarlılık oluşturmaktadır. Ağrı'da ön plana çıkan görüş, başkanlık sisteminin Türkiye şartlarına uygun olmadığ1 yönündedir. Cevaplayıcıların çoğunluğu mevcut parlamenter sistemin devam etmesi noktasındaki görüşlerini iki temel noktaya atıf yaparak söylemektedirler. Birincisi, demokrasi kültürünün ülkemizde henüz tam anlamıyla yerleşmemiş olduğu, ikincisi ise buna bağlı olarak başkanlık sisteminin ilerde baskıcı bir yapıya dönüşme riski taşıyor olması. Bu gerekçelere dayanarak konuşmacıların büyük bir kısmı, mevcut sistemin esasen toplumumuza uygun olduğunu ancak iyi işletilmediği için sorunlar yaşadığımızı dile getirdiler. Başka bir deyişle esas sorunun siyasal sistem ile ilgili değil siyasal aktörlerle ilgili olduğu ifade edildi.

\subsubsection{Yerel yönetimleri güçlendiren bir anayasa}

Cevaplayıcıların ön plana çıkardıkları konulardan biri de yerel yönetimlerin merkezi yönetim ile olan ilişkisidir. Bu konudaki görüşler 
çeşitlilik göstermektedir. Ortaya çıkan görüşlere baktığımızda, federasyon benzeri siyasal yapılanmaların anayasal düzenlemelerle tesis edilmesi yönündeki taleplerin diğer taleplerin gerisinde kaldığını görmekteyiz. Ortak kanaat ise yerel yönetimlerin yetkilerinin artırılması yönündedir. Merkezi otoritenin çıkardığı kararların çoğu zaman yerel gerçekliklerle bağdaşmadığ ve bunun pek çok sakınca doğurduğu ifade edilmiştir. Bu konuda cevaplayıcılar tarafından altı çizilen sakıncaların başlıcaları şunlardır: Öncelikle, merkezden alınan kararlar kimi zaman yerel gerçeklerden uzak kaldığı için, merkezi kararların bağlayıcı yönü sorgulanmaktadır. Buna ek olarak merkezi otorite ile yerel yönetimler arasında uyuşmazlıklar ve hatta kimi zaman çatışmalar yaşanmaktadır. Bu da kamu yönetiminde verimliliği azaltmakta ve uzun vadede toplumsal barışı tehdit etmektedir.

\subsubsection{Barajlar öfke biriktirir: Barajsı siyasal temsil öngören bir anayasa}

Siyasal temsili düzenleyen \%10'luk seçim barajı Türk siyasal hayatında uzun yıllardan beri tartışma konusudur. Tartışmanın taraflarının çokluğu ve farklı fikirlerin dolaşımda olması bu konu hakkında halkın duyarlılık geliştirmesine yol açmıştır. Araştırmamızda yer alan cevaplayıcıların bu konuda ön plana çıkardıkları ortak görüş, yeni anayasa ile tam demokrasiye geçilecekse seçim barajının makul bir seviyeye indirilmesi gerektiği yönündedir. Bu noktada cevaplayıcıların genelinin ortak kanaatini şöyle ifade edebiliriz: Yeni anayasa mecliste farklı görüşten olanların temsiliyeti için gerekli düzenlemeleri yapmalı, milletin iradesinin meclise yansıması noktasındaki kanalları açık tutmalı ve farklı fikirlerin bir zenginlik olduğu düşüncesinin altını çizmelidir.

\subsubsection{Tek tip "tebaa" değil çok renkli, çok dilli, çok kültürlü "yurttaşlar" toplumu}

Yeni anayasanın toplumun bütün kesimlerini kapsayan bir "toplumsal sözleşme" metni olabilmesi için en önemli noktalardan biri yurttaşlik tanımına ilişkin alacağı tutumdur. Yaptığımız mülâkatlardan çıkan en önemli sonuçlardan biri bununla ilgilidir. Cevaplayıcıların "yurttaşlık" tanımına ilişkin büyük bir hassasiyet içerisinde olduğunu söyleyebiliriz. Bu durumun somut ifadesini bir cevaplayıcının sözleri ile aktaracak olursak: "Yeni anayasa beni, 'Ne Mutlu Türküm diyene' söylemek zorunda birakmasın". Öte yandan yöre insanının bu konuda görüş belirtirken kullandığı dilin ayrımcılıktan öte uzlaşma kültürüne katkı yapan bir ton taşıdığını rahatlıkla ifade edebiliriz. Başka bir konuşmacının diline yansıyan şu sözler uzlaşma kültürünün altını çizmektedir: "Ben Kürdüm ama Türkiye vatandaşıyım”. Bu sözler yeni anayasanın kesinlikle etnik aidiyetlere vurgu yapmayan, "eşitlik 
içinde birliği savunan" ve anayasal yurttaşlığı merkeze alan bir anlayışla kaleme alınmasının elzem olduğunu göstermektedir.

\section{Sonuç}

Çalışma, yeni anayasadan beklentilerin hangi başlıklar etrafinda yoğunlaştığını ortaya koymaktadır. Bu yönüyle araştırmamız, hukukî değil sosyolojik bir araştırma olarak görülmelidir. Öte yandan, anayasa yapma süreci hukuki olduğu kadar politik ve sosyolojik bir süreçtir aynı zamanda. $\mathrm{Bu}$ nedenle araştırmamızda ortaya çıkan bazı hukukî boyutların da altının çizilmesi gerekir. Hukukî bakımdan ortaya çıkan noktaların en önemlisi, yeni anayasa yapma sürecinin meşruiyeti ile ilgilidir. Araştırmamız, yeni bir anayasa yapma, üstelik bu süreci bir an önce tamamlama konusunda bir beklenti olduğunu ortaya koymaktadır. Yeni bir anayasa yapma ile ilgili siyasal iradenin meşruiyeti, anayasa hukukçuları tarafından tartışılmaktadır. $\mathrm{Bu}$ konuda ön plana çıkan güçlü itirazlardan biri, yeni anayasa yapma sürecinin meşruiyet sâiklerini sorgulamaktadır. Araştırmamızda ortaya çıkan, yeni bir anayasa yapmanın gerekliliği ve ivediliği yönünde Ağrı'daki beklenti, bu meşruiyet ile ilgili bir ipucu olarak görülebilir. Bu beklentinin ülke çapında ne ölçüde yaygın olduğunu bulmak ise daha geniş çaplı bir araştırma gerektirir.

Araştırmanın ortaya koyduğu önemli noktalardan biri de, Ağrı halkının yeni anayasayı, ülkemizde yıllardır yaşanan ve hâl-i hazırda yaşanmaya devam eden toplumsal sorunlara çözüm bulabilecek bir metin olarak gördüğüdür. Yeni anayasanın, kronikleşmiş etnik, dinsel ve mezhepsel sorunlara gerçekten bir çözüm bulup bulamayacağ1 veya teorik olarak yeni bir anayasaya böyle işlevlerin atfedilmesinin doğru olup olmadığı ayrı bir tartışma konusudur. Ancak araştırmamızın ortaya koyduğu veriler, Ağrı halkının bu konuda anayasadan önemli beklentiler içerisinde olduğunu göstermektedir. Yeni anayasanın toplumsal farklılıkları garanti altına alan, özellikle anadil konusunda duyarlı bir metin olması yönünde bir beklentinin olduğunu söyleyebiliriz.

Araştırmamız tarafından ortaya konan bir başka bulgu ise, yeni anayasanın politik işlevlerine dair beklentilerle ilgilidir. Ağrı halkı, özellikle yeni anayasa yapılması ile ilgili tartışmalarla birlikte ön plana çıkan "başkanlık sistemi” önerisine sıcak bakmamaktadır. Ağrı'da Adalet ve Kalkınma Partisi'nin oylarının yüksek bir oranda olduğunu ve başkanlık sistemi önerisinin Adalet ve Kalkınma Partisi tarafından gündeme getirildiğini ve savunulduğunu düşünürsek, bu şaşırtıcı bir sonuçtur. Ağrı'da hâkim olan kanaat, mevcut sistemin başkanlık sisteminden daha iyi olduğu ve yeni anayasanın da bu politik sistemi garanti altına alması gerektiği yönündedir. 
Ayrıca araştırmamız, yeni anayasa yapma konusunda halkın geçmiş anayasalardan farklı olarak aktif olması gerektiğine dair bir beklenti içerisinde olduğunu göstermektedir. Yeni anayasanın halkın onayından geçmesi gerektiği yönündeki beklenti, yeni anayasanın meşruiyeti ile ilgilidir ve araştırmamız halkın bu meşruiyetin ne anlama geldiğinin farkında olduğunu göstermektedir.

\section{Kaynakça}

ABELES, Marc. (1995) Devletin Antropolojisi, İstanbul: Kesit Yayıncilik.

ALDIKAÇTI, Orhan. (1973) Anayasa Hukukumuzun Gelişmesi ve 1961 Anayasası, İstanbul: İstanbul Üniversitesi Yayınları.

AKGÜN, Seçil Karal. (2010) "Ellinci Yılında 27 Mayıs Hareketi ve 1961 Anayasasının Türkiye'de Anayasal Kültürün Oluşumundaki Rolü”, Mülkiye Dergisi, Cilt XXXIV, Say1 267, s. 145-166.

BULUT, Nihat. "Sosyal Devletin Düşünsel Temelleri ve Çağdaş Sosyal Devlet Anlayıș1"”, http://www.jura.uni-sb.de/turkish/NBulut2.html , erişim: 21 Eylül 2013.

GÖZLER, Kemal. (2013) Türk Anayasa Hukukuna Giriş, Bursa: Ekin Yayınc1lik.

GÜLENER, Serdar. (2011) “Anayasa Yapımında Yeni Bir Paradigma: Kapsayıc1, Katılımcı, Uzlaşmacı Anayasa Yapım Süreçleri ve Çeşitli Örnekler", Gazi Üniversitesi Hukuk Fakültesi Dergisi, Sayı, 3, s. 199-224.

HEPAKSAZ, Engin ve AKDEMIR, Tekin. (2010) "Türkiye'de Yeni Anayasa Tartışmalarının ve 1982 Anayasası'nın Vergisel Hükümlerinin Toplumsal Sözleşme Teorisi Açısından Değerlendirilmesi”, Erciyes Üniversitesi Ikktisadi ve Ticari Bilimler Fakültesi Dergisi, Say1, 35, Ocak Temmuz, s. 119-147.

İLAL, Ersan. (1968) "Magna Carta", İstanbul Üniversitesi Hukuk Fakültesi Mecmuası, Cilt 34, Say1 1-4, s. 210-242.

NEWMAN, Isadore and BENZ, Carolyn R. (1998) QualitativeQuantitative Research Methodology: Exploring the Interactive Continuum, Illinois: Southern Illinois University Press.

OKANDAN, Recai G. (1946) "Amme Hukukumuz Bakımından Tanzimat, Birinci ve İkinci Meşrutiyet Devirlerinin Önemi”, İstanbul Üniversitesi Hukuk Fakültesi Mecmuası, Cilt 15, Sayı 1, s. 14-33.

ÖZBUDUN, Ergun. (2000) Türk Anayasa Hukuku, Ankara: Yetkin Yayınları. 
PERAKYLA, Anssi. (2008), "Analyzing Talk and Text" in Norman K. Denzin ve Yvonna S. Lincoln, The Sage Handbook of Qualitative Research, London: Sage Publications, pp. 869-886.

SEIDMAN, Irving. (2006) Interviewing as Qualitative Research, New York: Teachers College.

TANÖR, Bülent. (1995) Osmanl-Türk Anayasal Gelişmeleri (17891980), İstanbul: Der Yayınlar1.

YAZICI, Sedat ve YAZICI, Fatih. (2011) "Tarihsellik ve Kuramsallık Arasında: 1921 ve 1924 Anayasalarında Kuvvetler Birliği-Ayrılığ Tartışması", Bilig Dergisi, Sayı 59, Güz, s. 235-254.

YÜZBAŞIOĞLU, Necmi. (2013) Anayasa Hukukunun Temel Metinleri, İstanbul: Beta Yayınları. 